\title{
COMPARISON OF K-TYPE AND T-TYPE THERMOCOUPLES FOR STABILITY AND UNIFORMITY OF INFANT INCUBATOR TEMPERATURE TESTING BASED ON IEC 60601-2-19
}

\section{Perbandingan Termokopel K dan T untuk Pengujian Stabilitas dan Uniformitas Suhu Inkubator Bayi Berdasarkan IEC 60601-2-19}

\author{
Nurdina Gita Pratiwi ${ }^{1}$, Siddiq Wahyu Hidayat ${ }^{1}$, Wuwus Ardiatna ${ }^{1}$, Chery Chaen Putri ${ }^{2}$ \\ ${ }^{1}$ Research Center for Testing Technology, Indonesian Institute of Sciences \\ PUSPITEK area, Building 417, Setu, South Tangerang, Banten, Indonesia, 15314 \\ ${ }^{2}$ Center for Research and Human Resources Development, National Standardization Agency of Indonesia \\ PUSPIPTEK area, Building 420, Setu, South Tangerang, Banten, Indonesia, 15314 \\ e-mail: n.gitapratiwi@gmail.com
}

Diterima: 17 Juli 2019, Direvisi: 3 Oktober 2019, Disetujui: 14 November 2019

\begin{abstract}
Infant incubator is one of the most important medical devices for newborn survival, especially preterm. However, aside from its benefits, some irregularities can be found on the devices that could lead to infant mortality, such as temperature deviations. The problem can be minimized by testing the infant incubator temperature parameter in accordance with IEC 60601-2-19 standard. However, there are various types of temperature sensors for related tests. Therefore K-Type and T-Type Thermocouples are compared in order to provide recommendations for infant incubator testing. The measurement technique used were referred to the instructions stated in IEC 60601-2-19 sub-clause Stability (with tolerance $\pm 0.5^{\circ} \mathrm{C}$ ) and sub-clause Uniformity (with tolerance $\pm 0.8^{\circ} \mathrm{C}$ ). For $\mathrm{K}$-type thermocouples, the highest stability results at $32^{\circ} \mathrm{C}$ is $-0.2^{\circ} \mathrm{C}$ and at $36^{\circ} \mathrm{C}$ is $-0.4^{\circ} \mathrm{C}$, while the highest uniformity results at $32^{\circ} \mathrm{C}$ is $-0.1^{\circ} \mathrm{C}$ and at $36^{\circ} \mathrm{C}$ is $-1.6^{\circ} \mathrm{C}$, with the uncertainty of $1.7^{\circ} \mathrm{C}$. For T-type thermocouples, the highest stability results at $32^{\circ} \mathrm{C}$ is $0.4^{\circ} \mathrm{C}$ and at $36^{\circ} \mathrm{C}$ is $-0.4^{\circ} \mathrm{C}$, while the highest uniformity results at $32^{\circ} \mathrm{C}$ is $0.7^{\circ} \mathrm{C}$ and at $36^{\circ} \mathrm{C}$ is $0.8^{\circ} \mathrm{C}$, with the uncertainty of $0.3^{\circ} \mathrm{C}$. The results of the independent $\mathrm{t}$-test showed a different average, where the T-type thermocouples was higher than the K-type thermocouples. In other words, T-type thermocouples could be recommended for infant incubators testing.
\end{abstract}

Keywords: IEC 60601-2-19, K-type Thermocouple, Stability, T-type Thermocouple, Uniformity, Independent t-test

\section{Abstrak}

Inkubator bayi merupakan peralatan medis yang sangat penting untuk kelangsungan hidup bayi yang baru lahir, khususnya bayi prematur. Namun disamping manfaat tersebut, terdapat penyimpangan alat yang juga dapat berdampak pada kematian bayi, contohnya penyimpangan suhu. Untuk dapat meminimalisir hal tersebut, parameter suhu pada inkubator bayi perlu diuji menggunakan standar IEC 60601-2-19. Sedangkan terdapat berbagai macam sensor suhu untuk pengujian terkait. Oleh karenanya termokopel $T$ dan $K$ dibandingkan dalam rangka memberikan rekomendasi untuk pengujian inkubator bayi. Teknik pengukuran yang digunakan mengikuti sub-klausul Stabilitas (toleransi $\pm 0.5^{\circ} \mathrm{C}$ ) dan Uniformitas (toleransi $\pm 0.8^{\circ} \mathrm{C}$ ) Inkubator bayi pada standar IEC 60601-2-19. Untuk termokopel $\mathrm{K}$, hasil stabilitas terbesar pada suhu $32^{\circ} \mathrm{C}$ adalah $-0.2^{\circ} \mathrm{C}$ dan pada suhu $36^{\circ} \mathrm{C}$ adalah $-0.4^{\circ} \mathrm{C}$, sedangkan hasil uniformitas terbesar pada suhu $32^{\circ} \mathrm{C}$ adalah $-1.0^{\circ} \mathrm{C}$ dan pada suhu $36^{\circ} \mathrm{C}$ adalah $1.6^{\circ} \mathrm{C}$, dengan ketidakpastian sebesar $1.7^{\circ} \mathrm{C}$. Untuk Termokopel $\mathrm{T}$, hasil stabilitas terbesar pada suhu $32^{\circ} \mathrm{C}$ adalah $0.4^{\circ} \mathrm{C}$ dan pada suhu $36^{\circ} \mathrm{C}$ adalah $-0.4^{\circ} \mathrm{C}$, hasil uniformitas terbesar pada suhu $32^{\circ} \mathrm{C}$ adalah $0.7^{\circ} \mathrm{C}$ dan pada suhu $36^{\circ} \mathrm{C}$ adalah $0.8^{\circ} \mathrm{C}$, dengan ketidakpastian sebesar $0.3^{\circ} \mathrm{C}$. Hasil independent $t$-test menunjukkan ratarata yang berbeda, dimana termokopel $T$ lebih tinggi dibandingkan dengan termokopel K. Dengan kata lain, termokopel $T$ dapat direkomendasikan untuk pengujian inkubator bayi, sedangkan termokopel K tidak.

Kata kunci: IEC 60601-2-19, Termokopel K, Termokopel T, Stabilitas, Uji T, Uniformitas.

\section{INTRODUCTION}

Newborn in the first 24-hour phase needs to adapt to their new environment. These newborns are stress prone due to changes in environmental temperature from warm intra uterine to colder extra uterine while newborns tend not to be able to regulate their body temperature perfectly in extreme environments. Drastic body heat loss or hypothermia could cause the infant to ill or even death.

To prevent newborns from experiencing hypothermia, they must be placed in an incubator. The use of incubators has proven to 
have a direct impact on the survival rate of newborns since its application at the end of the 19th century. At the time, research showed that the mortality rate of infants under $2 \mathrm{~kg}$ decreased from $66 \%$ to $38 \%$ (Badnjevic, Gurbeta, Jimenez, \& Ladanza, 2017).

Despite these benefits, there is an unlikely misuse of the device that has potential to cause severe injury or infant death. FDA MAUDE (Food and Drug Administration Manufacturer and User Facility Device) of the United States of America stated that there were 6 deaths and 23 injuries from a total of 42 malfunctions incubators in the period of 2006-2016 (Antonucci, Porcella, \& Fanos, 2009). The slightest output temperature deviations such as $\pm 20 \mathrm{C}$, could have a considerable impact on the survival of the infant (de Araújo et all., 2013). Due to the very specific configuration requirements for the infant's condition, the use of this incubator is very important to minimize risks and still need further studies to maximize its benefits.

To reduce malfunctioning equipment, incubators performances need to be tested. The test procedures of incubator are performed in accordance to international standards, namely IEC 60601-2-19: 2009 concerning on Particular Requirements for Basic Safety and Essential Performance of Infant Incubators. One of the parameters tested is temperature. However, there are various temperature sensors which are not necessarily suitable to conduct the related test. Some commonly used temperature sensors include thermocouple, RTD, thermistor, and IC form sensors. Each type of sensor has the characteristics, advantages and disadvantages.

Thermocouples is one of the temperature sensor that is commonly used because it is easy to use and relatively cheaper. The type of thermocouple that is often used for industry is Ktype thermocouple. It is because it has wide range of temperature (from $-200^{\circ} \mathrm{C}$ until $1260^{\circ} \mathrm{C}$ (Kerlin \& Johnson, 2012). However, the problem is the K-type thermocouple is not the type with the smallest error limit. Based on the datasheet, the smallest error limit for temperatures above $0^{\circ} \mathrm{C}$ is carried by T-type thermocouple (Desmarais \& Breuer, 2001). To prove that Ttype thermocouple is better than K-type thermocouple, specially for the purposes of incubator testing, both thermocouples should be compared. Therefore the study of this paper is to verify whether both, one, or nor both type of $\mathrm{T}$ type and K-type thermocouples can be recommended for testing incubators by performing the stability and the uniformity test based on the standard.

\section{BASIC THEORY}

The procedure of infant incubator temperature testing which is stated in IEC 60601-2-19 standard, does not mention what type of temperature sensor is used, considering that there are 4 types of temperature sensors discussed in the introduction. The research conducted by Altayyai, Ali, and Hussein (2016), Olivera, Rocha, Rotger \& Herrera (2011), and A. Badnjevic et al, (2017) used the Fluke INCU sensor for infant incubator temperature testing. Another study that conducted by Hidayat, A. R., Hidayat, S. W. and Ardiatna (2013) used K-type thermocouples.The K-type thermocouple is basically capable of measuring infant incubator temperature, aside from the use of fluke INCU. Beside the K-type thermocouple, There are various types of thermocouples including $T, J, N$, $E, R, B, S$ which all have their own characteristics.

Thermocouples are the most commonly used temperature sensors, because of not only its relatively inexpensive but also its accurate. In principle, the thermocouple consists of two wires (hot and cold transducers) which are connected together to produce electric motions that arise from a difference between its connections (Wardoyo, Habibie \& Wiryadinata, 2016). some of the advantages of the thermocouple are simple (needs only 2 cables), diverse types, and its wide range of temperature. On the other hands, the drawbacks of thermocouple are not linear, requires a compensation circuit, low voltage, less stable and less sensitive.

A thermocouple, shown in Figure 1, consists of two wires of dissimilar metals joined together at one end, called the measurement junction. The other end, where the wires are not joined, is connected to the signal conditioning circuitry traces, typically made of copper. This junction between the thermocouple metals and the copper traces is called the reference junction (Duff \& Towey, 2010).

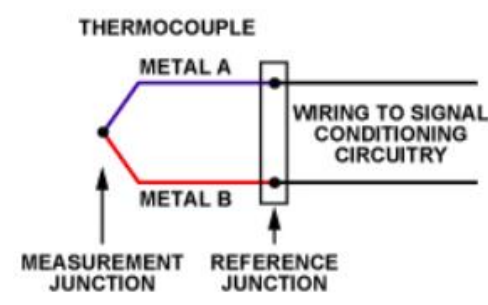

Figure $1 \mathrm{~A}$ thermocouple. 
To determine the process temperature, thermocouples use a phenomenon known as the Seebeck effect. A voltage measured at a thermocouples's cold junction is proportional to the temperature difference between the hot junction and the cold junction, according to the Seebeck effect. The voltage measured at the cold junction is frequently referred to as Seebeck voltage, thermoelectric voltage, or the thermoelectric EMF. As the hot junction temperature rises, the observed voltage at the cold junction also enhances by a quantity that is almost linear to the rise in temperature (McMillan \& Toarmina, 2011).

For the reference point, an ice bath was used. Thermocouple calibration data for a reference temperature of $0^{\circ} \mathrm{C}$ were developed into normal practice. For the standard thermocouple types for the reference temperature of $0^{\circ} \mathrm{C}$, Figure 2 indicates the emf versus the measured junction temperature. This calibration could be used to achieve the temperature of the junction when the referral end was put in an ice bath (Kerlin \& Johnson, 2012).

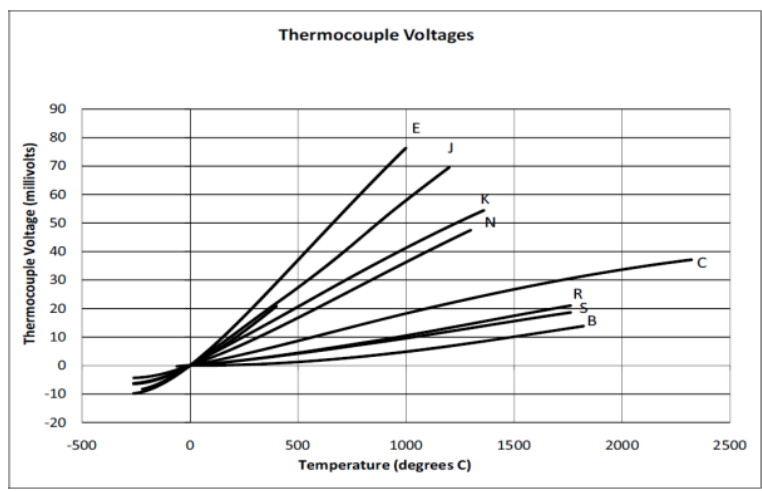

Figure 2 Thermoelectric EMFs for Standard Thermocouples.

During operation, Infant Incubator has particular graph of Time vs. Temperature that is shown in Figure 3. In the first adjustment, the temperature will rise and reach its maximum peak. Afterwards, the temperature will overshoot and achieve steady condition.

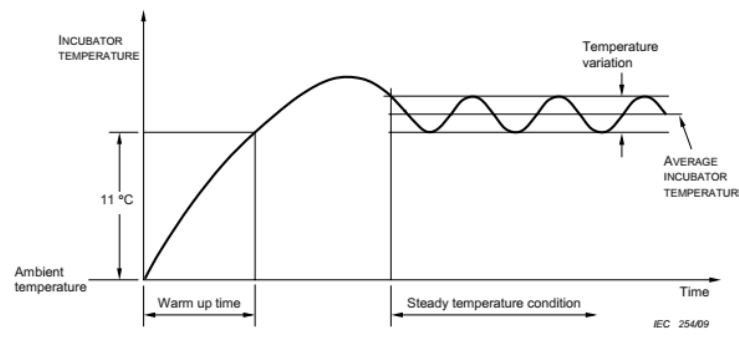

Figure 3 Variation of Incubator Temperature (IEC60601-2-19).
Based on the standard IEC 60601-2-19, the stability requirement for infant incubator temperature that state in clause 201.12.1.101 is a steady condition where the temperature fluctuations will not differ $0.5^{\circ} \mathrm{C}$ from its average temperature. Measurement of this stability is performed above the centre point of the mattress at the height of $10 \mathrm{~cm}$. While, the uniformity of infant incubator that state in clause 201.12.1.102 is a steady condition where the temperature of infant incubator is uniform with the limit of $0.8^{\circ} \mathrm{C}$. The measurement is performed by comparing centre points of four areas formed by line (Point $A, B, C, D$ ) with the temperature on the centre of the mattress (Point $M$ ) at the height of $10 \mathrm{~cm}$ above the matress, as shown in Figure 4.

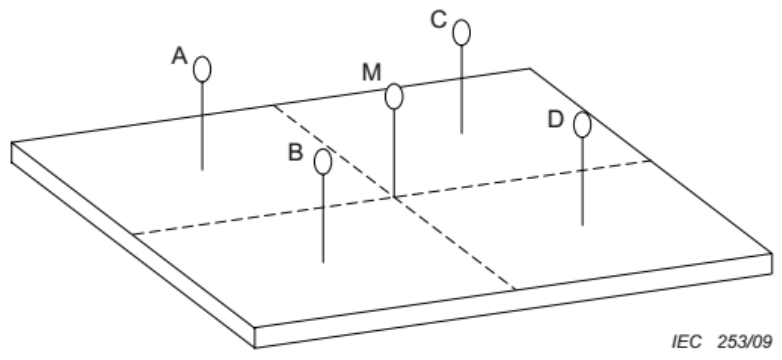

Figure 4 Measurement Point based on IEC 60601-2-19.

\section{METHODS}

Data retrieval is carried out by following the standards of IEC 60601-2-19 sub-clause of stability and uniformity of infant incubators. Each K-type and T-type thermocouple is connected to a different data logger with the same time setting. Both thermocouples is then placed side by side at 5 measurement points in the infant incubator compartment $10 \mathrm{~cm}$ above the mattress, as shown in the Figure 5. The $M$ point is the midpoint of the infant incubator compartment while points $A, B, C$, and $D$ are the midpoints of the division of 4 sides. Environmental temperature is maintained between $21-26^{\circ} \mathrm{C}$. Measurements were taken at the incubator control temperature of $32{ }^{\circ} \mathrm{C}$ and $36^{\circ} \mathrm{C}$ for 1 hour after the incubator warmed up and reached a stable condition. The tolerance limit allowed for the stability of the baby incubator is $\pm 0.5^{\circ} \mathrm{C}$, which is the deviation between the $\mathrm{M}$ measurement points against its average. While the tolerance limit for the uniformity of a baby incubator is $\pm 0.8^{\circ} \mathrm{C}$, which is the deviation value between points $A, B, C$, and $D$ with the average value at point $\mathrm{M}$. 


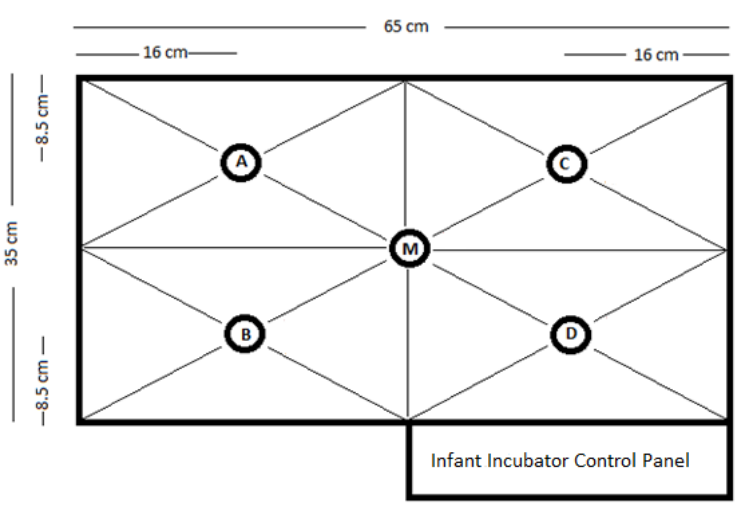

Figure 5 Point measurement sketch inside infant incubator.

The measurement results of the K-type and T-type thermocouples are added with a correction factor from the calibration certificate. Then the measurement uncertainty is calculated using ISO GUM (Guide to The Expression of Uncertainty Measurement). Evaluation of uncertainty includes evaluation of type $A$ and type B. Evaluation of type A is an evaluation of uncertainty measurement with statistical methods, which in this study is the standard deviation of repetition of measurements. The type $B$ evaluation is an evaluation of uncertainty measurement with methods other than statistics, such as uncertainty from the certificate of tool calibration and the reading device resolution.

The results of the processed data are also analyzed using unpaired $T$ test statistics to find if there is any significant differences between the two thermocouples.

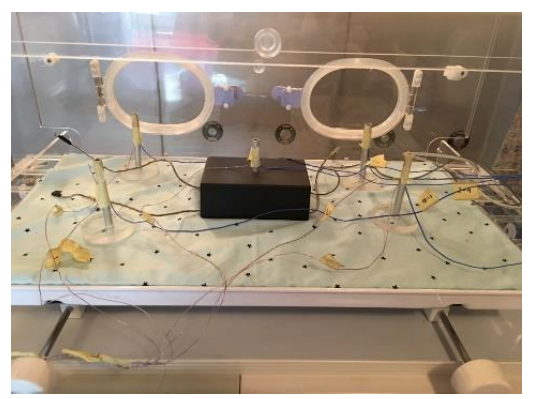

Figure 6 Incubator temperature measurement using thermocouple K-type and T-type.

\section{RESULT AND DISCUSSION}

The result was taken from 205 measurements at temperature of $32^{\circ} \mathrm{C}$ and 206 measurements at $36^{\circ} \mathrm{C}$ with recorded time of 1 hour. The plotting graphs in this paper were the measurement result that being added by the correction factor. Figure 7 shows the K-type thermocouple at $32{ }^{\circ} \mathrm{C}$ and T-type thermocouple readings result was shown on Figure 8. The average room temperature during the test at $32^{\circ} \mathrm{C}$ is $23.5^{\circ} \mathrm{C}$ and the humidity in the incubator compartment during the test at $32^{\circ} \mathrm{C}$ is $52 \%$.

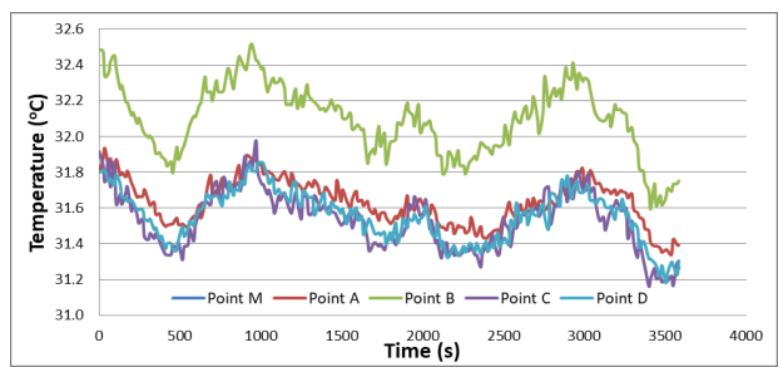

Figure 7 Temperature vs. Time read by K-type Thermocouple at $32^{\circ} \mathrm{C}$.

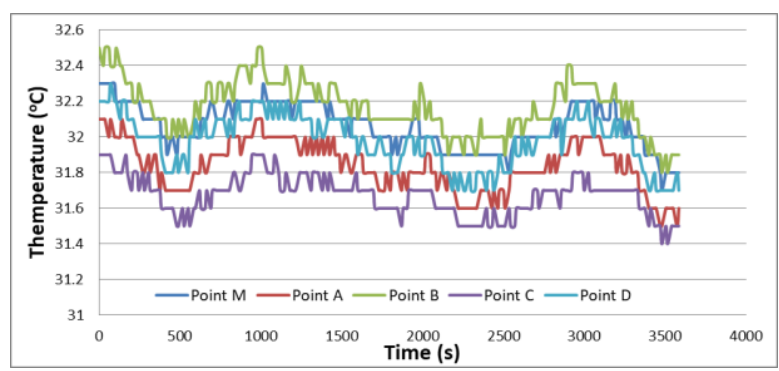

Figure 8 Temperature vs. Time read by T-type Thermocouple at $32^{\circ} \mathrm{C}$.

The reading results on thermocouple $T$ type at $32^{\circ} \mathrm{C}$ more uniform compared to K-type thermocouples. In K-type thermocouples, point B has a higher measurement result compared to points $M, A, C$, and $D$. The phenomenon occurs because the part is close to the heating channel which has a higher output temperature. However the other point has lower result than the T-type. At the same point of this measurement (point B) of T-type thermocouple shows the higher result too, if it was compared to the others points.

The measurement result for the $36^{\circ} \mathrm{C}$, are shown in the Figure 9 and Figure 10 During the measurement, the average room temperature at $36{ }^{\circ} \mathrm{C}$ is $24.2{ }^{\circ} \mathrm{C}$ while the humidity in the incubator compartment during the test at $36^{\circ} \mathrm{C}$ is $41 \%$.

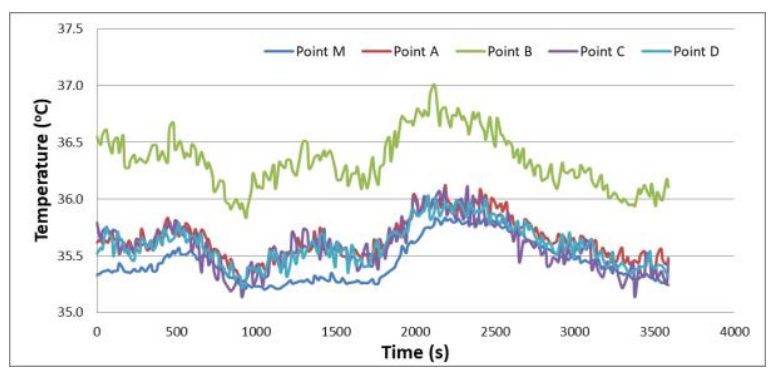

Figure 9 Temperature vs. Time read by K-type Thermocouple at $36^{\circ} \mathrm{C}$. 


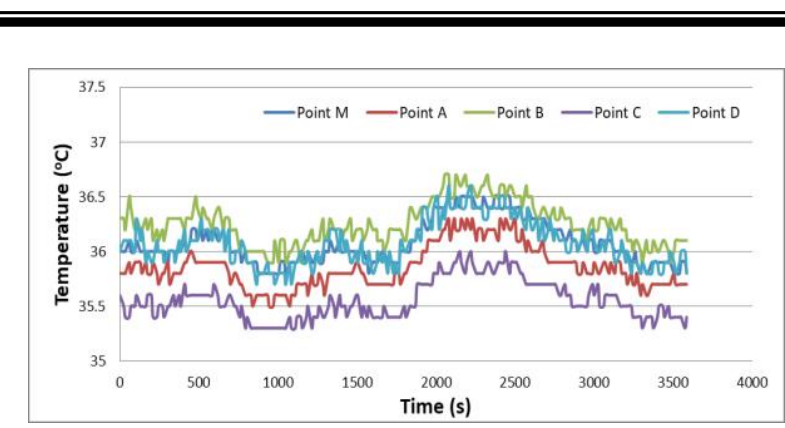

Figure 10 Temperature vs. Time read by T-type Thermocouple at $36^{\circ} \mathrm{C}$

The measurement result at both $32^{\circ} \mathrm{C}$ and $36^{\circ} \mathrm{C}$, have difference value, it is because of the Seekbeck coeffient value of $\mathrm{K}$ and the T-Type of thermocouple is different. The T-type at $0^{\circ} \mathrm{C}$ the output changes at $39 \mu \mathrm{V} /{ }^{\circ} \mathrm{C}$, but at $100^{\circ} \mathrm{C}$, the slope increases to $47 \mu \mathrm{V} /{ }^{\circ} \mathrm{C}$, and for the K-type's Seebeck coefficient is roughly constant at about $41 \mu \mathrm{V} /{ }^{\circ} \mathrm{C}$ from $0^{\circ} \mathrm{C}$ to $1000^{\circ} \mathrm{C}$, based on its characteristic.

Table 1 Measurement results of the average, deviation standard, and independent T-test.

\begin{tabular}{|c|c|c|c|c|c|c|c|}
\hline $\begin{array}{c}\text { Them- } \\
\text { perature }\end{array}$ & Point & $\begin{array}{l}\text { Thermo- } \\
\text { couples }\end{array}$ & $\mathrm{N}$ & Mean & SD & t-test & $\begin{array}{c}p- \\
\text { value }\end{array}$ \\
\hline \multirow{10}{*}{32} & \multirow{2}{*}{ M } & $\mathrm{K}$ & 205 & 31.5 & 0.1 & \multirow{2}{*}{--48.3} & \multirow{2}{*}{0.00} \\
\hline & & $\mathrm{T}$ & 205 & 32.1 & 0.1 & & \\
\hline & \multirow{2}{*}{ A } & K & 205 & 31.6 & 0.1 & \multirow{2}{*}{-15.2} & \multirow{2}{*}{0.00} \\
\hline & & $\mathrm{T}$ & 205 & 31.8 & 0.1 & & \\
\hline & \multirow{2}{*}{ B } & $\mathrm{K}$ & 205 & 32.1 & 0.2 & \multirow{2}{*}{-4.1} & \multirow{2}{*}{0.00} \\
\hline & & $\mathrm{T}$ & 205 & 32.2 & 0.2 & & \\
\hline & \multirow{2}{*}{ C } & K & 205 & 31.5 & 0.2 & \multirow{2}{*}{-9.7} & \multirow{2}{*}{0.00} \\
\hline & & $\mathrm{T}$ & 205 & 31.7 & 0.1 & & \\
\hline & \multirow{2}{*}{ D } & $\mathrm{K}$ & 205 & 31.6 & 0.1 & \multirow{2}{*}{--29.1} & \multirow{2}{*}{0.00} \\
\hline & & $\mathrm{T}$ & 205 & 32.0 & 0.1 & & \\
\hline \multirow{10}{*}{36} & \multirow{2}{*}{ M } & $\mathrm{K}$ & 206 & 35.5 & 0.2 & \multirow{2}{*}{--33.2} & \multirow{2}{*}{0.00} \\
\hline & & $\mathrm{T}$ & 206 & 36.1 & 0.2 & & \\
\hline & \multirow{2}{*}{ A } & $\mathrm{K}$ & 206 & 35.6 & 0.2 & \multirow{2}{*}{--11.7} & \multirow{2}{*}{0.00} \\
\hline & & $\mathrm{T}$ & 206 & 35.9 & 0.2 & & \\
\hline & \multirow[b]{2}{*}{ B } & K & 206 & 36.3 & 0.2 & \multirow{2}{*}{3.9} & \multirow{2}{*}{0.00} \\
\hline & & $\mathrm{T}$ & 206 & 36.3 & 0.2 & & \\
\hline & \multirow{2}{*}{ C } & K & 206 & 35.6 & 0.2 & \multirow{2}{*}{1.6} & \multirow{2}{*}{0.12} \\
\hline & & $\mathrm{T}$ & 206 & 35.6 & 0.2 & & \\
\hline & \multirow{2}{*}{ ) } & K & 206 & 35.6 & 0.2 & \multirow{2}{*}{ - -24.6 } & \multirow{2}{*}{0.00} \\
\hline & & $\mathrm{T}$ & 206 & 36.1 & 0.2 & & \\
\hline
\end{tabular}

The results of the combined uncertainty evaluation obtained from the calculation. The uncertainty result for the K-type thermocouple is $1.7^{\circ} \mathrm{C}$ and for thermocouple T-type is $0.3^{\circ} \mathrm{C}$. The uncertainty value of thermocouple K-type is too large to use for testing incubators. It is because the uniformity testing for the incubator has limit, and if the K-type is used to measure, the result will exceeded the limit.

In general, Table 1 showed that T-type thermocouple has a higher average and the standard deviation tends to be the same compared to K-type thermocouple. However, the results of independent $T$ test showed that the two averages have nothing in common. It is proven by a $p$ value smaller than 0.05 . Only at $36^{\circ} \mathrm{C}$ at point $C$, the two thermocouples have $p$ value $=$ 0.12 and it is mean that at point $C$ has not significantly different from 2 types of thermocouple. It can be shown that the mean value at $C$ has the same result for both thermocouples. This result can be occurred during the measurement, because temperature may changes or even stable, that makes the both thermocouples show the same result.

\section{A. Stability of Infant Incubator Temperature}

Figures 11 and 12 explain the stability of an incubator. The $y$ axis is the temperature deviation between the measurements at point $M$ with its average value. The average $M$ point at $32{ }^{\circ} \mathrm{C}$ for K-type thermocouple is $31.5^{\circ} \mathrm{C}$ and $\mathrm{T}$ type thermocouple is $35.1^{\circ} \mathrm{C}$. While the average at point $\mathrm{M}$ at $36^{\circ} \mathrm{C}$ for $\mathrm{K}$-type thermocouples is $35.5^{\circ} \mathrm{C}$ and thermocouple T-type is $36.1^{\circ} \mathrm{C}$.

At $36^{\circ} \mathrm{C}$ the graph shows that at 1800 second to 2000 second the graph trends is drop and continue to stable until 2500 second, and start to increase again up to the end of the measurement. However, this temperature value is still within the specification limit.

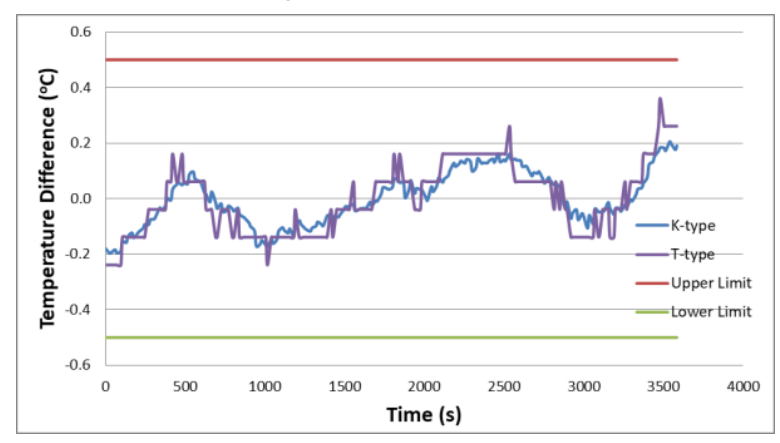

Figure $11 \mathrm{M}$ point deviation value vs time at $32^{\circ} \mathrm{C}$. 


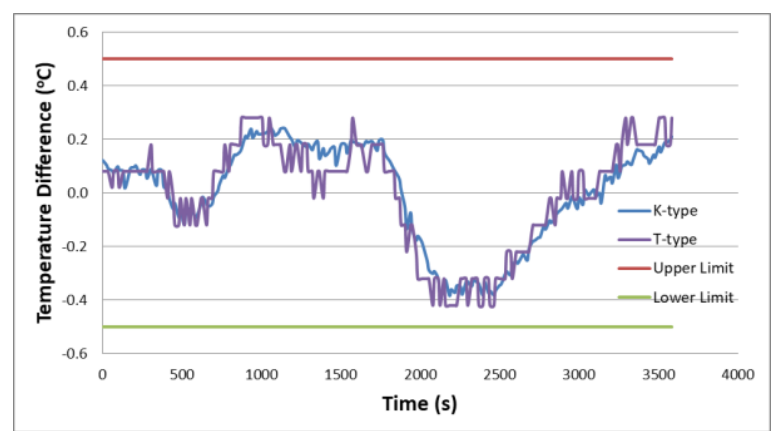

Figure $12 \mathrm{M}$ point temperature deviation vs. Time at $36^{\circ} \mathrm{C}$.

\section{B. Uniformity of Infant Incubator Temperature}

Figures 13 to Figure 16 show the results of uniformity of an infant incubator for K-type and Ttype thermocouples at temperatures of $32^{\circ} \mathrm{C}$ and $36^{\circ} \mathrm{C}$. The $y$ axis is the temperature deviation between measurements at points $A, B, C$, and $D$ with an average at point $M$. In thermocouple $T$ type (Figures 14 and 16), the uniformity results are within the $\pm 0.8^{\circ} \mathrm{C}$ limit, whereas for K-type thermocouples (Figures 13 and 15) there is a value that exceeds the limit, which at point $B$ with the furthest value at $-1.6^{\circ} \mathrm{C}$.

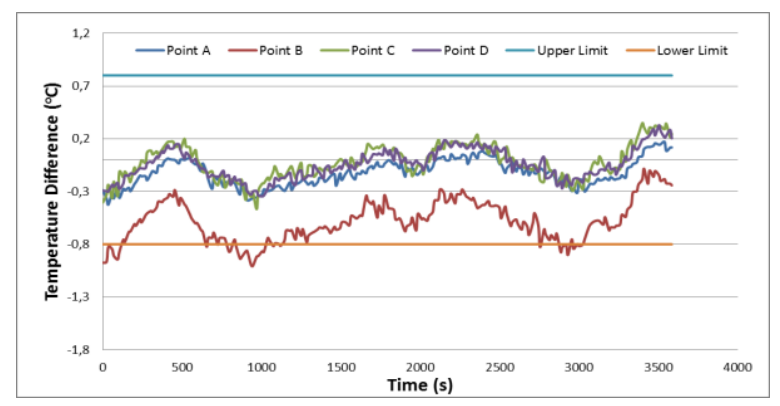

Figure 13 Temperature deviation at point $A, B, C$, and $D$, vs. Average $M$ value at $32^{\circ} \mathrm{C}$ using $\mathrm{K}$-type Thermocouples.

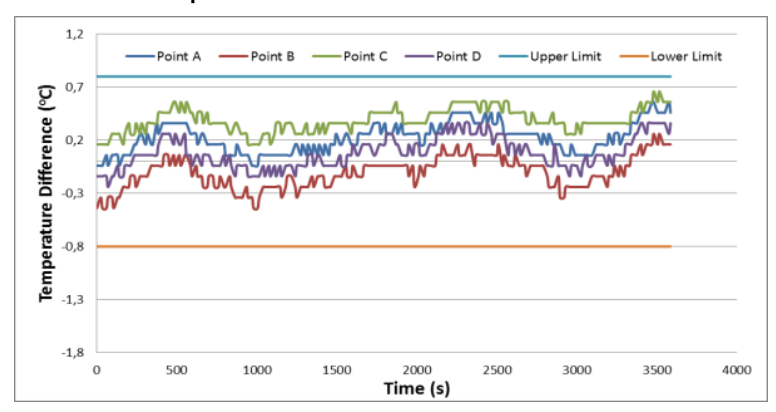

Figure 14 Temperature deviation at point A, B, C, and $D$, vs. Average $M$ value at $32^{\circ} \mathrm{C}$ using $T$ type Thermocouples.

Even though, it has big deviation value, the overall average of the deviation still within the specification. However, during the measurement it cannot be neglected, since the result is two times of the limit specified, and it need further study to verify the root cause of the big deviation on each thermocouple. It cannot because of the thermocouple but also the system during the measurement, and also the environment that can be one of the root cause.

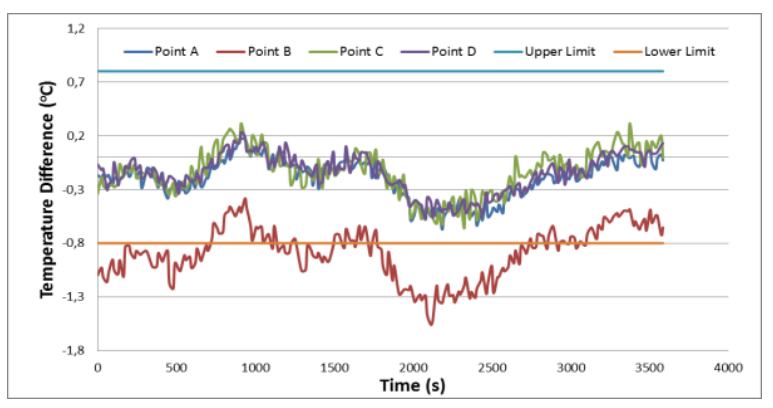

Figure 15 Temperature deviation at point $A, B, C$, and $\mathrm{D}$, vs. Average $\mathrm{M}$ value at $36^{\circ} \mathrm{C}$ using $\mathrm{K}$ type Thermocouples

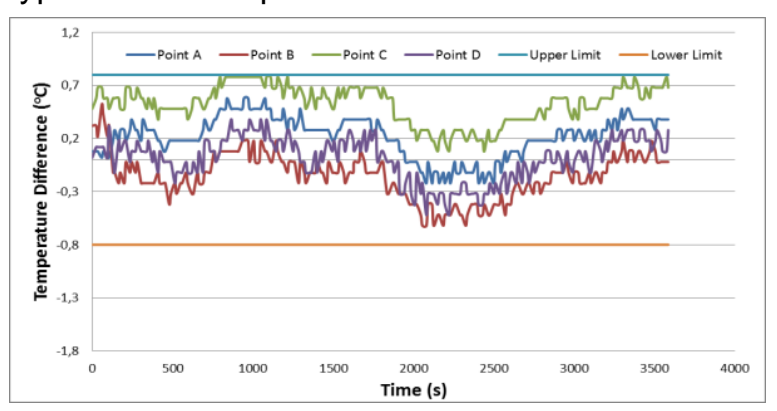

Figure 16 Temperature deviation at point $A, B, C$, and $D$, vs. Average $M$ value at $36^{\circ} \mathrm{C}$ using $\mathrm{T}$ type Thermocouples

Based on the stability and the uniformity test above, then the $\mathrm{K}$ and the T-type of thermocouple can be summarized into Table 2 .

Table 2 minimum and maximum deviation value of stability and uniformity of infant incubator temperature

\begin{tabular}{lccccccccc}
\hline \multirow{3}{*}{ Sub-Clause } & \multicolumn{1}{c}{ K-type Thermocouples } & \multicolumn{3}{c}{ T-type Thermocouples } \\
\cline { 2 - 9 } & \multicolumn{2}{c}{$32{ }^{\circ} \mathrm{C}$} & \multicolumn{2}{c}{$36^{\circ} \mathrm{C}$} & \multicolumn{2}{c}{$32^{\circ} \mathrm{C}$} & \multicolumn{3}{c}{$36^{\circ} \mathrm{C}$} \\
\cline { 2 - 9 } & $\min$ & $\max$ & $\min$ & $\max$ & $\min$ & $\max$ & $\min$ & $\max$ \\
\hline Stability & -0.2 & 0.2 & -0.4 & 0.2 & -0.2 & 0.4 & -0.4 & 0.3 \\
\hline Uniformity & -0.1 & 0.3 & -1.6 & 0.3 & -0.4 & 0.7 & -0.6 & 0.8 \\
\hline
\end{tabular}

The uniformity maximum value of T-types of thermocouple is $0.8^{\circ} \mathrm{C}$, and it is within the specification. However the K-type thermocuple, has the biggest deviation value. In this case, the T-Type of thermocouple is suitable to for testing.

\section{CONCLUSION}

The stability results of infant incubators using thermocouples K-type and T-type are identical and within the limit. While the results of 
uniformity, only the $\mathrm{T}$ thermocouple has four measurement points that meet the limit. For $\mathrm{K}$ thermocouples, measurement of infant incubator uniformity gives the farthest result of 2 times the limit.

Independent $\mathrm{T}$ test calculations between thermocouples K-type and T-type do not show the same average value; with thermocouple has higher T-types values. Evaluation of the uncertainty of the thermocouple T-type combination is much smaller than K-type.

From these results it can be concluded that the thermocouple T-type is recommended for testing the temperature of an incubator. On the contrary, thermocouple K-type is not recommended to used for testing incubators.

\section{ACKNOWLEDGEMENT}

Authors would like to express gratitude to the following researchers group of electromedic for the discussion: Ihsan Supono Ph.D, Sutrisno Salomo Hutagalung S.Si, M.T., Asep Rahmat Hidayat S.T., M.Si.

\section{DAFTAR PUSTAKA}

Altayyai, S. S., Ali, M. O. M. and Hussein, H. M. (2016). The accuracy of temperature monitoring of the incubator for newborns. IFMBE Proc,57, 1052-1054.

Antonucci, R., Porcella, A., \& Fanos, V. (2009). The infant incubator in the neonatal intensive care unit: unresolved issues and future developments. Journal of perinatal medicine, 37(6), 587-598.

Badnjevic, A., Gurbeta, L., Jimenez, E. R., \& ladanza, E. (2017). Testing of mechanical ventilators and infant incubators in healthcare institutions. Technology and health care, 25(2), 237-250.

Baker, J. P. (2000). The incubator and the medical discovery of the premature infant. Journal of Perinatology, 20(5), 321328. de Araújo, J., de Menezes, J., Moura de Albuquerque, A., da Mota Almeida, O., \& Ugulino de Araújo, F. (2013). Assessment and certification of neonatal incubator sensors through an inferential neural network. Sensors, 13(11), 15613-15632.

Desmarais, R., \& Breuer, J. (2001). How to Select and Use the Right Temperature Sensors. Sensors, 18, 24-36

Duff, M., \& Towey, J. (2010). Two ways to measure temperature using thermocouples feature simplicity, accuracy, and flexibility. Analog Dialogue, 44(10), 1-6.

Hidayat, A. R., Hidayat, S. W., and Ardiatna, W. (2013). Analisis pengukuran homogenitas temperatur ruang inkubator bayi. Annu. Meet. Test. Qual, XIII, (1907-7459), 2329, 2013.

Kerlin, T. W., \& Johnson, M. (1999). Practical thermocouple thermometry. Instrument Society of America.

Kumar, R., \& Aggarwal, A. K. (1996). Accuracy of maternal perception of neonatal temperature. Indian pediatrics, 33, 583584.

Kumar, V., Shearer, J. C., Kumar, A., \& Darmstadt, G. L. (2009). Neonatal hypothermia in low resource settings: A review. Journal of Perinatology, 29(6), 401.

McMillan, G. K., \& Toarmina, C. M. (2011). Advanced Temperature Measurement and Control. International Society of Automation.

Olivera, J. M., Rocha, L. A., Rotger, V. I., \& Herrera, M. C. (2011). Acoustic pollution in hospital environments. Journal of Physics: Conference Series, 332(1), 012003. IOP Publishing.

Wardoyo, S., Habibie, A. P., \& Wiryadinata, R. (2016). Wireless Data Logger Suhu Multi Channel Menggunakan Labview. Jurnal Nasional Teknik Elektro dan Teknologi Informasi, 5(2), 129-134. 
